\title{
Nanoemulsion containing caffeine for cellulite treatment: characterization and in vitro evaluation
}

\author{
Thamires Batello Freire ${ }^{\circledR 1^{*}}$, Michelli Ferrera Dario ${ }^{1}$, Otávio Gil Mendes ${ }^{2}$, Andressa Costa de \\ Oliveira $^{1}$, Alberto Vetore Neto ${ }^{1}$, Dalva Lucia Araújo de Faria ${ }^{2}$, Vânia Rodrigues Leite e Silva ${ }^{3}$, \\ André Rolim Baby ${ }^{1}$, Maria Valéria Robles Velasco ${ }^{1}$
}

\begin{abstract}
${ }^{1}$ Department of Pharmacy, Faculty of Pharmaceutical Sciences, University of São Paulo, São Paulo, Brazil, ${ }^{2}$ Department of Fundamental Chemistry, Chemistry Institute, University of São Paulo, São Paulo, Brazil, ${ }^{3}$ Department of Exact and Earth Sciences, Institute of Environmental Sciences, Chemistry and Pharmaceuticals São Paulo, Federal University of São Paulo, São Paulo, Brazil
\end{abstract}

\begin{abstract}
The Ginoide Hydrolipodystrophy (GHLD), commonly known as cellulite, occurs in $80-90 \%$ of the female population after the puberty period and comes from a metabolic modification in the cutaneous adipose tissue. Caffeine has been used in topical formulations due to its lipolytic action. We studied a nanoemulsion (F3) containing caffeine with two surfactants (oleth-3 and oleth-20) by emulsification method by phase inversion temperature inversion (PIT). The polydispersion indices (PDI) showed the reduced deviation of 0.1 . The mean droplet size was $\sim 40 \mathrm{~nm}$. The evaluated constant of Ostwald, in the refrigerator condition was the most favorable during the stability test. In the In Raman spectroscopy assay, the caffeine bands found in F3 were compatible with those found in the caffeine solution (1337, 652.5 and $\left.558.2 \mathrm{~cm}^{-1}\right)$. There was no interaction of caffeine anhydrous with other ingredients in nanoemulsion. In the in vitro safety assay the result of 1.4 ranked the $\mathbf{F 3}$ as slightly irritating. In the natural membrane, cutaneous permeation test (human skin) permeate concentrations did not exceed the saturation concentration of the PBS buffer $(48.96 \mu \mathrm{g} / 3 \mathrm{~mL}$ ). The caffeine solution and $\mathbf{F 3}$ permeated statistically equal, but the nanoemulsion visually and sensorially improved the caffeine precipitation.
\end{abstract}

Keywords: Cellulite. Caffeine. Gynoid hydrolipodystrophy. Nanoemulsion. Permeation.

\section{INTRODUCTION}

Gynoid Hydrolipodystrophy (GHLD), a modification of the cutaneous relief due to morphological, histochemical, biochemical and ultrastructural change in the skin, occurs around 80 to $90 \%$ of the female population after puberty, appearing in the pelvic, lower limb and abdomen regions (Santos et al., 2011).

The dermoepidermal changes, with an increase in the size and number of adipocytes (hypertrophy and hyperplasia, respectively), are responsible for the skin alteration resulting in the orange peel appearance. These changes become more pronounced due to the fixation of the septa to the dense fibrous connective tissue covering the blood vessels, nerves, bones and muscles (deep fascia

\footnotetext{
*Correspondence: T. B. Freire. Departamento de Farmácia, Faculdade de Ciências Farmacêuticas, Universidade de São Paulo. Av. Prof. Lineu Prestes, 580, B1-13/15, 05508-900, São Paulo - SP, Brazil. Fax: 5511 3815-4418. Phone: 5511 3091-3623
}

or muscular fascia). In addition, these septa are fixed with the reticular dermis, linking both (Guirro, Guirro, 2007). Considering the most accepted theories for the pathophysiology of GHLD, researchers tend to develop topical cosmetic formulations containing active ingredients with a microvascular, lymphatic flow stimulatory and lipolytic effects (Ramalho, Curvelo, 2006). Among these ingredients are the methylxanthines (caffeine, theophylline, aminophylline), retinol, phosphatidylcholine, L-carnitine, ginkgo biloba, methyl nicotinate, menthol, camphor and silicon (Krupek, Costa, 2013).

Caffeine, the most widely used methylxanthine, acts on the metabolism of adipocytes and promotes the inhibition of the phosphodiesterase enzyme (Krupek, Costa, 2013; Bertin et al., 2001), which causes an increase in the cyclic adenosine monophosphate (cAMP). This mechanism results in lysis of triacylglycerol in fatty acid plus glycerol (lipolysis) (Rawlings, 2006; Ribeiro, 2010). The efficacy of caffeine was previously revealed 
by reducing $17 \%$ of adipocyte diameter in an animal model (albino/Wistar rats) using an oil-in-water emulsion containing 4\% w/w caffeine (Velasco et al., 2008).

Furthermore, caffeine is considered a model of hydrophilic skin-permeation substance in animal and human membranes, but it tends to precipitate and may lead to the formation of clumps of difficult redispersion depending on the vehicle used (Herman, Herman, 2013; Fernandes et al., 2015). Thus, an innovative formulation, which can address this drawback of the conventional formulation, will allow improving the sensorial hindered by the precipitation of the caffeine.

According Yukuyama et al. (2016), the superior property of a nanoemulsion compared to a macroemulsions is explained by the following characteristics: small droplet size ensures uniform distribution on the skin, large surface area, modified release, better film formation on the skin, high stability, pleasant aesthetic character and skin feel.

The formulation can be classified as nanoemulsion because of the droplet size. However, the ranges vary, according to the authors, between 20-500 $\mathrm{nm}$ (Mei et al., 2011), (50-500 nm) (Tadros et al., 2004) and from 20 to $200 \mathrm{~nm}$ (Izquierdo et al., 2004). Also, the droplet size influences its appearance droplet size influences its appearance since formulation can be transparent or translucent (50-200 nm) or milky (up to $500 \mathrm{~nm}$ ) (Izquierdo et al., 2002).

The key factor for obtaining a successful nanoemulsion is the selection of most suitable process and components, which ensure the desired properties of the final obtained nanodroplets (Yukuyama et al., 2016). Among the methods mentioned in the scientific literature, the Phase Inversion Temperature (PIT) of the emulsions uses low energy, it has low cost and it is simple to execute (Shinoda, Saito, 1968; Mei et al., 2011; Dario et al., 2016). These characteristics qualified it for this research.

Several methods are employed in the preparation; this research used low energy methods. This method provides inversion phase by variations in the volume fraction or temperature variations known as Phase Inversion Temperature (PIT) emulsification (Shinoda, Saito, 1968).

Thus, the purpose of the present work was to develop a nanoemulsion containing caffeine $(1 \% \mathrm{w} / \mathrm{v})$ with two surfactants (oleth-3 and oleth-20 using a low energy process, the Phase Inversion Temperature, and its physicalchemical characterization and in vitro efficacy evaluation.

\section{MATERIAL AND METHODS}

Caffeine Anhydrous (Henrifarma) of 101.0\% purity, caffeine anhydrous (Sigma Aldrich) analytical reference standard of purity of $100 \%$, sodium chloride (Pharma Special), capric/caprylic triglyceride (Mapric), phenoxyethanol (and) parabens (Phenonip ${ }^{\circledR}$, Pharma Special) were purchased. Oleth-3 and oleth-20 were kindly donated by Croda.

\section{Preparation of nanoemulsion containing caffeine}

The nanoemulsions were developed by the sub-PIT method. About $100 \mathrm{~g}$ of each formulation were prepared by varying the proportion of the two nonionic surfactants necessary for the formation of the nanoemulsion (oleth-20 and oleth-3), keeping the sum of their proportion in the formulation $(11.2 \% \mathrm{w} / \mathrm{w})$, with final EHL of 11.1 (Table I) (Dario et al., 2016; Mei et al., 2011; Roger, Cabane, Olsson, 2010). The proportion of caffeine $(1.0 \% \mathrm{w} / \mathrm{w})$ was chosen according to the literature (Sintov, Greenberg, 2014). This proportion is according with the Brazilian law of cosmetic products (Brazil, 2002; Shakeel, Ramadan, 2010; Fotticchia et al., 2014). The value of $\mathrm{pH}$ was corrected for 5.7.

The components of the formulations were mixed and heated under magnetic stirring (approximately $350 \mathrm{rpm}$ ) until reaching $80.0 \pm 5.0^{\circ} \mathrm{C}$, the temperature at which the minimum turbidity was observed and below the PIT (Mei et al., 2011). Subsequently, the formulation was rapidly cooled in an ice bath to $\sim 40.0^{\circ} \mathrm{C}$.

\section{Normal Stability Assay (NSA)}

The stability of the nanoemulsion was tested by simultaneously maintaining separate samples in the oven $\left(45.0 \pm 2.0^{\circ} \mathrm{C}\right)$, in the refrigerator $\left(5.0 \pm 2.0^{\circ} \mathrm{C}\right)$ and at room temperature $\left(25.0 \pm 2.0^{\circ} \mathrm{C}\right)$ for 90 days (Dario et al., 2016; Brazil, 2004). Possible changes in organoleptic properties (appearance, color, and odor). The $\mathrm{pH}$ was determined with a Quimis ${ }^{\circledR}$ pHmeter. The droplet mean diameter and the polydispersity index were determined by Dynamic Light Scattering (DLS) at an angle of $90^{\circ} \mathrm{C}$ at $25^{\circ} \mathrm{C}$. The zeta potential was determined at a field strength of $20 \mathrm{~V} / \mathrm{cm}$. Both analyses was performed in a Malvern ZetaSizer Nano ZS90 (Kaszuba, 2015).

\section{Ostwald ripening constant}

From the data obtained in NSA test, the Ostwald ripening constant was calculated according to the methodology described by Dario et al. (2016).

\section{Nanoemulsion Raman Spectroscopy}

A spectrometer (Renishaw in Via Reflex), equipped 
TABLE I - Qualitative and quantitative composition (\% w/w) of the preparations (1 to 6)

\begin{tabular}{|c|c|c|c|c|c|c|}
\hline Ingredients* & F1 & F2 & F3 & F4 & F5 & F6 \\
\hline 1. Caprylic/capric triglyceride & 5.0 & & & & & \\
\hline 2. Oleth-3 & 9.4 & 6.7 & 5.6 & 0.6 & 6.2 & 4.2 \\
\hline 3. Oleth-20 & 1.8 & 4.5 & 5.6 & 10.6 & 5.0 & 7.0 \\
\hline 4. Sodium chloride & \multicolumn{6}{|c|}{2.0} \\
\hline $\begin{array}{l}\text { 5. (phenoxyethanol (and) methylparaben } \\
\text { (and) ethylparaben (and) butylparaben (and) } \\
\text { propylparaben (and) isobutylparaben) }\end{array}$ & \multicolumn{6}{|c|}{0.5} \\
\hline 6. caffeine & \multicolumn{6}{|c|}{1.0} \\
\hline 7. acqua qsp & \multicolumn{6}{|c|}{100.0} \\
\hline
\end{tabular}

qsp: sufficient quantity to; ${ }^{*}$ INCI Name: International Nomenclature of Cosmetic Ingredient

with a thermally cooled and coupled camera (CCD) (Renishaw $600 \times 400$ pixels) was coupled to a microscope (Leica, model: DM2500M); the laser line at $785 \mathrm{~nm}$ (diode laser, Renishaw) was focused on the sample by an objective (Leica) with a 50x magnification (numerical aperture of 0.75). Samples were placed on a carrier for liquid samples and spectra were recorded in the $400-1800 \mathrm{~cm}^{-1}$ range with the laser power at approximately $10 \mathrm{~mW}$ in the sample. Anhydrous caffeine spectra and caffeine solutions were compared at several values of $\mathrm{pH}$ in order to verify the possible protonation, as well as the comparison of this active ingredient with other organic ingredients of the nanoemulsion (Gil, 2015).

\section{Entrapment Efficiency (EE\%)}

The caffeine encapsulation efficiency in the nanoemulsion droplets was determined by the difference between the total caffeine concentration and the free caffeine in the nanoemulsion. The quantification method of caffeine was previously validated by High-Performance Liquid Chromatography (HPLC). To calculate the free caffeine concentration, $300 \mu \mathrm{l}$ of the nanoemulsion was added to a $10 \mathrm{kDa}$ filtration unit (Amicon; Millipore, USA) and centrifuged at $21,400 \mathrm{~g}$ for $30 \mathrm{~min}$ at $25.0 \pm 1.0^{\circ} \mathrm{C}$. The caffeine in the supernatant was quantified and the encapsulation efficiency was calculated according to the Equation 1 (Oliveira et al., 2016).

$$
E E \%=\frac{C(T)-C(F)}{C(F)} \times 100
$$

where: EE: Entrapment Efficiency; $\mathrm{C}(\mathrm{T})$ : total concentration of caffeine; $\mathrm{C}(\mathrm{F})$ : concentration of free caffeine in the formulation

\section{In vitro safety evaluation}

The irritant potential was determined by the in vitro HET-CAM (Hen's Egg Test - Chorioallantoic Membrane) method. Fertile White Leghorn hen's eggs were kept in an incubator for 9 days at $37{ }^{\circ} \mathrm{C}$ and $65 \%$ relative humidity. After the incubation period, the chorioallantoic membrane (CAM) was exposed and hydrated with $0.9 \% \mathrm{NaCl}$ solution. On undamaged CAM, $300.0 \mu \mathrm{l}$ of F3 were applied (triplicate). The same aliquot of $1.0 \%$ sodium dodecyl sulfate (SDS) solution was applied as a positive control. The vascular events (hemorrhage, lysis or coagulation) were recorded for $300 \mathrm{~s}$ and the ocular irritation index was calculated (Kalweit et al., 1990; National Institute of Environmental Health Sciences, 2006).

\section{Skin permeation}

The in vitro permeation of caffeine was performed in two-compartment vertical diffusion cells (Franz cells) as described in United States Pharmacopeia, NF31 (USP, 2013) and Pharmacopeia Forum (2008) for semi-solid and transdermal products with modifications.

Human skin was taken from abdominal plastic surgery, cleaned and the subcutaneous fat was removed. The experiment was approved by the Ethics Committee of Faculty of Pharmacy/University of São Paulo, process number 516508.15.0.3001.0067. The skin was frozen at $-5.0^{\circ} \mathrm{C}$ and used one week later. After being rehydrated with Phosphate Buffered Saline (PBS), skin integrity was evaluated by transepidermal water loss (TEWL) method. This procedure is an approval or disapproval criterion for the skin (Gioia, Celleno, 2002; Paepe, Roseeuw, Rogiers, 2002). 
Caffeine quantification method was previously validated according to the literature (ICH, 2005; USP, 2013; Ribani et al., 2004). A $150 \mu \mathrm{l}(10 \mathrm{mg} / \mathrm{mL})$ aliquot of $\mathbf{F 3}$ was applied to the skin surface. PBS was used as receiving fluid, according to the Brazilian Pharmacopeia $5^{\text {th }}$ ed (2010) and placed in a heated bath at $32.0^{\circ} \mathrm{C}$, under constant agitation. The solubility of the substances in the receiving fluid was checked previously to the experiment. Samples were collected at times: $\mathrm{t} 0, \mathrm{t} 1, \mathrm{t} 2, \mathrm{t} 3, \mathrm{t} 4, \mathrm{t} 22$ and t24 h.

Epidermis and dermis were separated by the technique of immersion in water at $60{ }^{\circ} \mathrm{C}$ for 1 minute and 30 seconds, followed by mechanical separation of them with the aid of surgical tweezers. Afterwards, they were stored in glass vials with $10 \mathrm{~mL}$ of the buffer solution and subjected to mixing at $3000 \mathrm{rpm}$ for 2 minutes, 24 hours of rest and 20 minutes of sonication (Junyaprasert et al., 2009).

The concentration of caffeine was identified and quantified in 4 different skin regions: Skin Surface by Swab 2 (SP), Epidermis (E), Dermis (D) and receiving fluid (FR) by HPLC.

The concentration of caffeine accumulated in the skin was plotted as a function of time ( $\mathrm{t}$ ). The apparent permeability coefficient (Papp) was calculated using Equation 2 (Sintov, Greenberg, 2014).

$$
\text { Papp }=\frac{\Delta \mathrm{Q}}{\Delta \mathrm{t}} \times \frac{1}{\mathrm{~A}} \times \frac{1}{\mathrm{C}_{0}}
$$

where: Papp: apparent permeability coefficient, $\Delta \mathrm{Q}$ : accumulated caffeine concentration, $\Delta \mathrm{t}$ : time variation in hours, $\mathrm{A}$ : diffusion area in the donor compartment and $\mathrm{C}_{0}$ : initial concentration of caffeine in the nanoemulsion added in the donor compartment.

\section{Statistical analysis}

Statistical analysis was performed using Minitab software (Version 17), by one-way ANOVA followed by the Tukey test or 2-sample Student's T-Test. Differences were considered statistically significant at a value of $\mathrm{p}<0.05$.

\section{RESULTS AND DISCUSSION}

\section{Caffeine nanoemulsion preparation}

After the emulsion preparation, the $\mathbf{F} 3$ formulation with EHL of 11.1, with the more translucent aspect, was selected. This characteristic indicated a probable nanometric droplet size due to the high light spreadability
(Sarker, 2005). As this formulation presented PIT at $83.5^{\circ} \mathrm{C}$, the formulation was heated at $\sim 80.0^{\circ} \mathrm{C}$, the clearing-boundary temperature $\left(\mathrm{T}_{\mathrm{cb}}\right)$ when formulation became opalescent and slightly bluish (Mei et al., 2011).

The other formulations (F1, F2, F4 to F6) were not stable and/or more translucent than the $\mathbf{F 3}$ that was choseniced, because it occurred phase separation and very opalescent appearance, so they were not recorded to the others analyses.

Obtaining formulations by the sub-PIT method was accelerated by the addition of salts that provide the salting-out effect. In this work, the sodium chloride $(\mathrm{NaCl})$ was added in order to obtain the salting-out effect and, consequently, reducing $\mathrm{T}_{\mathrm{cb}}$ and avoid providing more energy to the system (Mei et al., 2011). The conductivity in an $\mathrm{O} / \mathrm{W}$ emulsion is due to the presence of electrolytes in the aqueous phase (Zhang, Michniak-kon, 2011). During the PIT emulsification process, at the PIT temperature occurs the inversion of phases, i.e, the oil phase becomes the continuous phase and the conductivity drops abruptly. Thus, the electrical conductivity of the formulations is an indicator of phase inversion. As soon as the PIT temperature was achieved, the formulation must be cooled quickly, preferably in an ice bath. This process inverted the phases again, yielding an emulsion with reduced droplet diameter, that is, an $\mathrm{O} / \mathrm{W}$ nanoemulsion (Mei et al., 2011).

By the exposed, the measurement of the conductivity, as well as the determination of PIT, became commonly used methods to characterize nanoemulsions. The temperature that initiated the phase inversion in $\mathbf{F 3}$ was $82.0{ }^{\circ} \mathrm{C}$ and at $85.0{ }^{\circ} \mathrm{C}$ the lowest conductivity value occurred. Following, the formulation was cooled in an ice bath, the conductivity presented values near the initials, indicating the return of the state of nanoemulsion $\mathrm{O} / \mathrm{W}$. This conductivity profile was similar to the one found in the literature. Due to their thermodynamic instability, emulsions tend to reduce their free energy and interfacial area through some degradation process, such as cremation/ sedimentation, aggregation, flocculation, coalescence and Ostwald ripening (Mei et al., 2011).

\section{Characterization of nanoemulsion}

By the graphs of intensity distribution, number and volume of $\mathbf{F 3}$, it could be concluded that the preparation method used (sub-PIT) was effective in obtaining monodisperse nanoemulsion. Nanoemulsion F3 presented a mean droplet diameter equal to $\sim 40 \mathrm{~nm}$. The polydispersity index (PDI) was lower than 0.3 adequate according to the literature (Kaszuba, 2015; Dario et al., 2016; Anton, Vandamme, 2008). 


\section{Normal Stability Assessment}

During the NSA, F3 did not have the organoleptic properties (appearance, color and odor) changed during the 90 days of the test, when stored at $25.0 \pm 20^{\circ} \mathrm{C}$ (room temperature) and $5.0 \pm 2.0^{\circ} \mathrm{C}$ (refrigerator). However, at $45.0 \pm 2.0^{\circ} \mathrm{C}$, the formulation became opaque whitish and presented phase separation before 7 days because the hightemperature condition usually leads to greater instability in the formulations (Baby et al., 2007; Pianovski et al., 2008; Dario et al., 2016). For this reason, the data of size, polydispersity and zeta were not registered for this condition. These results indicated that high temperatures storage conditions should be avoided.

The $\mathrm{pH}$ value is an important parameter for monitoring the stability of emulsions as changes in this value indicate the occurrence of chemical reactions that may compromise the quality of the final product and its shelf-life. Emulsions formulated with vegetable oils, such as capric/caprylic acid triglycerides, may have their $\mathrm{pH}$ value decrease due to the hydrolysis of the esters of fatty acids which generate free fatty acids (Martini, 2005). In addition, the final $\mathrm{pH}$ of the nanoemulsion may exert an influence on the extent of ionization of the interface components.

The $\mathrm{pH}$ values of $\mathbf{F 3}$ stored at $25.0 \pm 2.0^{\circ} \mathrm{C}$ and $5.0 \pm 2.0^{\circ} \mathrm{C}$ decreased over the 90 days of the assay $(\mathrm{pH}$ was 5.7 in $_{0}$ ). The results in the period between $t_{0}-t_{7}$ days presupposed time to stabilize the $\mathrm{pH}$ value, probably because the nanoemulsions are thermodynamically unstable (Dario et al., 2016). In the interval of $\mathrm{t}_{7}$ to $\mathrm{t}_{60}$ days the $\mathrm{pH}$ value was stable and close to the value 5.0 in both temperature conditions (room and refrigerator), Figure 1. The variation observed initially was within the range of physiological pH (4.0 - 6.0) (Pires, Pscheidt, 2017).

It is important to mention that the tendency to aggregation and sedimentation of dispersed nanoparticles, as a function of time, can be monitored by determining changes in particle size distribution (Schaffazick et al., 2003). Therefore, it is important to monitor particle size over time and during the NSA.

The PDI value remained constant at 0.2 at the refrigerator temperature $\left(5.0 \pm 2.0^{\circ} \mathrm{C}\right)$ while at room temperature condition $\left(25.0 \pm 2.0^{\circ} \mathrm{C}\right)$ this parameter dropped to 0.1 and remained constant, and it was considered adequate for both storage conditions (Nemen, Lemos-Senna, 2011; Anton, Vandamme, 2009; Kaszuba, 2015).

At $5.0 \pm 2.0^{\circ} \mathrm{C}$ the mean droplet diameter increased $21.7 \%$ after 90 days, while this parameter increased $50,8 \%$ at $25.0 \pm 2.0{ }^{\circ} \mathrm{C}$, which indicates that low

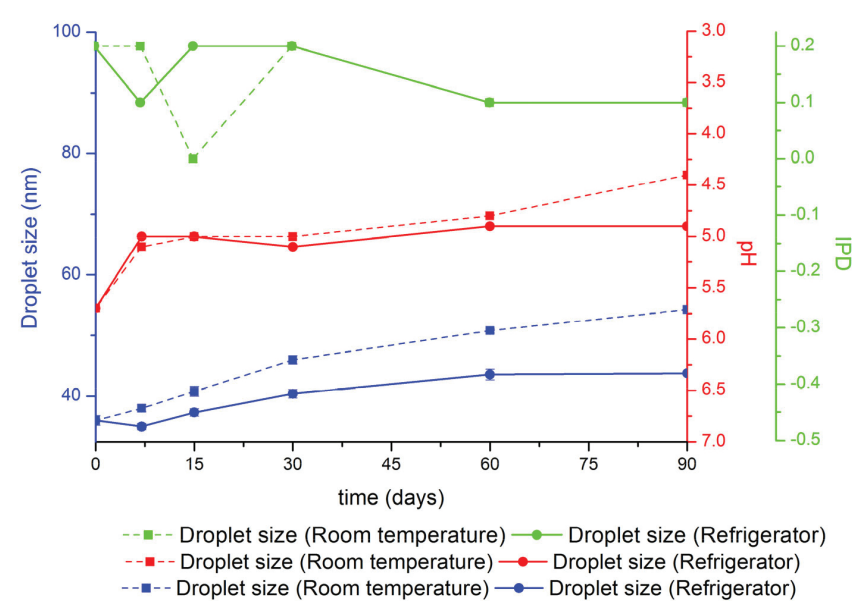

FIGURE 1 - Nanoemulsion F3: Droplet size, Polydispersion index (PDI) and $\mathrm{pH}$ value in the Normal Stability Assessment at $25.0 \pm 2.0^{\circ} \mathrm{C}$ (room temperature) and $5.0 \pm 2.0^{\circ} \mathrm{C}$ (refrigerator).

temperature (refrigerator) is the best condition of storage for this nanoemulsion. Due to the physical instability, this parameter was not assessed for the formulation storaged at $45.0 \pm 2.0^{\circ} \mathrm{C}$.

A likely explanation for emulsion instability is the maturation of Ostwald, known as Ostwald ripening. This is related to the instability rate of the dispersed phase component and can be described by using certain parameters, which are known as solubility coefficient, dispersed phase diffusion and interfacial tension between the droplets and the continuous phase. That is, the monomers of the surfactants below the critical micelle concentration (CMC) can migrate to other micelles increasing the size of existing micelles. However, concentrations above CMC do not have as much effect on stability once since the highest concentration of possible micelles was formed, stabilizing the medium (Rinaldo et al., 2012). The formation of an emulsion is related to its oil phase content and composition, especially the surfactant/oil phase ratio which determines the size of the emulsion droplets (Mei et al., 2011).

According to Martini (2005), the zeta potential was defined as the potential difference between the ions strongly attached to the particle surface and an uncharged neutral region of the solution, with a significant difference in viscoelasticity when compared to the solution adjacent to the droplets. When the zeta potential is $30 \mathrm{mV}$ (in modulus) or larger, the repulsive force of the double layer is greater than van der Waals' attractive force, thus avoiding possible flocculation. A high positive or negative value of the zeta potential is important for the physicochemical stability of the emulsion since the repulsive forces between the droplets 
prevent flocculation. Changes in the ionic atmosphere, such as that one caused by the addition of electrolytes, ionic surfactants and changes in the $\mathrm{pH}$ of the solution, can directly affect the charge of the droplet.

The zeta potential of $\mathbf{F 3}$ was, initially, $-3.9 \mathrm{mV}$ at $\mathrm{pH} 5.7$, due to the non-ionic surfactant used in the nanoemulsion. The probable explanation is due to the theory of the influence of the hydrogen bonds, and the negative surface charge was derived from the specific adsorption of hydroxyl ions directly from the formation of hydrogen bonds between hydroxyl ions and water molecules in the boundary layer. They also mentioned that the presence of fatty acids assists in the negative charge of the droplet (Mei et al., 2011). Once F3 has an ingredient with triacylglycerols in its composition, the negative interface attracts ions $\mathrm{H}^{+}$, these protonate the fatty acids and attenuate the negative charge resulting in a low value of zeta potential.

On the other hand, non-ionic surfactants, such as those used in F3 nanoemulsion, provide steric stability in the dispersed phase, delaying Ostwald ripening and coalescence (Kourniatis et al., 2010). The hydrophilic groups derived from the nonionic surfactants attract the water around them giving rise to a protective barrier that prevents coagulation, that justifies the stability of $\mathbf{F 3}$ (Oliveira, Mei, 2009).

\section{Ostwald ripening constant}

Emulsions and nanoemulsions are thermodynamically unstable systems, thus tending to destabilize during storage by various mechanisms, such as gravitational separation, flocculation, coalescence and Ostwald maturation. Emulsified systems should inhibit these mechanisms and provide enough kinetic stability to maintain the product's validity (Piorkowski, Mcclements, 2014).

At $25.0 \pm 2.0{ }^{\circ} \mathrm{C}$ there was a slightly better linear correlation for the parameter $\omega_{3}\left(\mathrm{R}^{2}=0.984\right)$ in relation to the parameter $\omega_{2}\left(R^{2}=0.969\right)$, suggesting that the diffusion of oil molecules was the first mechanism responsible for increasing the diameter of the drop in this temperature condition. The values of the Ostwald ripening constant in the room temperature condition $\left(25.0 \pm 2.0{ }^{\circ} \mathrm{C}\right)$ $\left(\omega_{2}=3.8 \times 10^{-5} \mathrm{~nm}^{2} \mathrm{~s}^{-1}\right.$ and $\left.\omega_{3}=0.01043 \mathrm{~nm}^{3} \mathrm{~s}^{-1}\right)$ were lower than the value mentioned by Wooster, Golding and Sanduansri (2008) $\left(\omega_{3}=0.0483 \mathrm{~nm}^{3} \mathrm{~s}^{-1}\right)$. Dario et al. (2016) obtained the best correlation for $\omega_{3}=2.5 \times 10^{-6} \mathrm{~nm}^{3} \mathrm{~s}^{-1}$, probably due to the addition of cetyltrimethylammonium chloride, a cationic surfactant to a similar formulation which improved the stability.
The values of the Ostwald ripening constant for $5.0 \pm 2.0{ }^{\circ} \mathrm{C}$ condition $\left(\omega_{2}=6.2 \times 10^{-6} \mathrm{~nm}^{2} \mathrm{~s}^{-1}\right.$ and $\left.\omega_{3}=0.0001 \mathrm{~nm}^{3} \mathrm{~s}^{-1}\right)$ were lower than those observed for at $25.0 \pm 2.0{ }^{\circ} \mathrm{C}$, which indicates that the storage at low temperatures (refrigerator condition) improves nanoemulsion stability. This phenomenon is observed because higher temperatures allow the oil to become more soluble in the aqueous phase promoting instability system (Dario et al., 2016).

\section{Raman spectroscopy}

The Raman spectra provide information about the structure of the vibrational transitions of molecules, assigning a wave number and specific bands, which can be called the "fingerprint" of the substances (Andreev et al., 2001), which is based on the results obtained in the literature.

Pavel et al. (2003) labeled some specific structural characteristics of the anhydrous caffeine molecule. The $\mathrm{N}^{7}$ methylated atom in the $v(\mathrm{CN})$ stretching occurs at 1408 $\mathrm{cm}^{-1}$, numbered in the molecular structure of caffeine as $\mathrm{N}^{7}-\mathrm{C}^{14}$. The draw $v(\mathrm{CN})$ at $\mathrm{C}^{2}-\mathrm{N}^{3}$ occurs at $1284 \mathrm{~cm}^{-1}$; the $v(\mathrm{CN})$ stretch at $\mathrm{C}^{8}-\mathrm{N}^{7}$ occurs at $1554 \mathrm{~cm}^{-1}$; The $\mathrm{C}^{14}-\mathrm{N}^{7}-\mathrm{C}^{8}$ deformation (CNC) occurs at $556 \mathrm{~cm}^{-1}$; The $\delta$ deformation $(\mathrm{HC}=\mathrm{N})$ in $\mathrm{C}^{8}-\mathrm{N}^{9}$ occurs at $1073 \mathrm{~cm}^{-1}$. In addition, the least specific molecular assignments were made for the modes $v(\mathrm{CN}, \mathrm{C}=\mathrm{C})$ and $v(\mathrm{CN})$ at 1600 e $1360 \mathrm{~cm}^{-1}$, respectively (Figure 2) (Pavel et al., 2003).

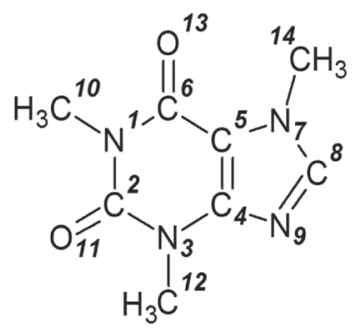

FIGURE 2 - Chemical structural of caffeine (Chemsketch software version 11, 2007; Tagliari et al., 2012).

Raman spectra of anhydrous caffeine are present in Figure 3, and values have been reported in the range of 400$1800 \mathrm{~cm}^{-1}$. The wave numbers of the bands are presented in the Table II and the vibrational assignments are provided for caffeine from data published by Pavel et al. (2003) and Matas et al. (1998). Edwards, Munshi and Anstis (2005) mentioned that water is easily lost from the crystalline mesh of caffeine and significant changes are observed in the stretches $v(\mathrm{C}=\mathrm{O})$ and in the region of the vibrational structure by the decrease of the intermolar attraction $\mathrm{CH}$... $\mathrm{OH}_{2}$ (Edwards, Munshi, Anstis, 2005). 
TABLE II - Raman spectrum and attributions for hydrated and anhydrous caffeine

\begin{tabular}{|c|c|c|}
\hline $\begin{array}{l}\text { Hydrated caffeine } \\
\text { pH } 7\end{array}$ & $\begin{array}{c}\text { Caffeine } \\
\text { anhydrous }\end{array}$ & Attribution \\
\hline $1643(\mathrm{~m})$ & $1657(\mathrm{~m})$ & $\begin{aligned} v(\mathrm{C}= & \mathrm{O}) \text { out of phase } \\
& +{ }_{\mathrm{v}}(\mathrm{C}=\mathrm{C})\end{aligned}$ \\
\hline 1337(s) & $1328(s)$ & $v($ ring imidazole $)$ \\
\hline $1296(\mathrm{~m})$ & 1284(m) & $v(\mathrm{C}-\mathrm{N})+\rho\left(\mathrm{CH}_{3}\right)$ \\
\hline $651.5(\mathrm{~m})$ & $642.9(\mathrm{~m})$ & $\begin{array}{c}\delta(\mathrm{OCN})+ \\
\delta(\text { anel imidazole } \\
\text { pirimidina })\end{array}$ \\
\hline $556.2(\mathrm{~s})$ & $555.4(\mathrm{~s})$ & $\begin{array}{c}\delta(\text { anel pirimidina })+ \\
\delta(\mathrm{CNC})+\rho\left(\mathrm{CH}_{3}\right)\end{array}$ \\
\hline
\end{tabular}

Legend: $(\mathrm{v})=$ stretch,$(\delta)=$ angular deformation; $(\mathrm{m})=$ medium, $(\mathrm{s})=$ strong, $(\rho)=$ translational mode, $($ Edwards, Munshi, Anstis, 2005; Pavel et al., 2003).

The difference in the position of the bands was used to show in which phase the caffeine is mostly found. The caffeine spectrum was compared in different $\mathrm{pH}$ values $(2.0 ; 5.0 ; 5.5 ; 6.0 ; 6.5$ and 7.0$)$ in order to verify the possible displacement of bands, which would suggest its protonation. This fact did not occur in the experimental conditions, which indicated that caffeine had no influence on the $\mathrm{pH}$ values evaluated.

The caffeine bands found in the $\mathbf{F 3}$ nanoemulsion were compatible with those found in the caffeine solution (bands 1337, 652.5 and $558.2 \mathrm{~cm}^{-1}$ ), probably due to their hydrophilicity and as it is in the hydrated form in the nanoemulsion (Figure 3). Caffeine has a hydrophilic character with $\log \mathrm{P}=-0.07$ and $\mathrm{pka}=8.3$ (Tagliari et al., 2012; Sintov, Greenberg, 2014; Abd et al., 2016).

The difference in the anhydrous caffeine compared to the solution was expressed by more intense bands displaced to the lowest wave number, Figure 3. The assignment of bands is in Table II. Displacements greater than $2 \mathrm{~cm}^{-1}$ are indicative of interactions (Gil, 2015). Thus, according to Table II, there was an interaction of the caffeine with the aqueous phase, probably due to its hydrophilic nature, except for the assignment corresponding to the $\delta$ (pyrimidine ring) $+\delta(\mathrm{CNC})+\rho$ (CH3) that has a lipophilic character.

\section{Entrapment Efficiency (EE\%)}

The obtaining method and formulation composition provided a low entrapment efficiency $(4.8 \%)$, probably due to the hydrophilicity of caffeine $(\log \mathrm{P}=-0,07)$ (Tagliari et al., 2012; Sintov; Greenberg, 2014; Abd et al., 2016). This result indicated that caffeine was mostly present in the continuous phase. As Hernández-Marín et al. (2016) achieved the encapsulation efficiency $>80 \%$ in caffeine multiples emulsions, water in oil nanoemulsion should be more efficient in order to improve the encapsulation efficiency (Hernández-marín et al., 2016).

\section{Eye irritation potential (HET-CAM)}

The Interagency Coordinating Committee on the Validation of Alternative Methods (ICCVAM) (2010) advocated that the results of HET-CAM test are valid only if the positive controls were classified as strongly irritating by the eye Irritation Index (I.I.). In this study, the positive control was considered highly irritating because presented eye I.I. $=1.4$. Hemorrhage was present only in one sample of the triplicate and no coagulation or lysis was observed (Figure 4).

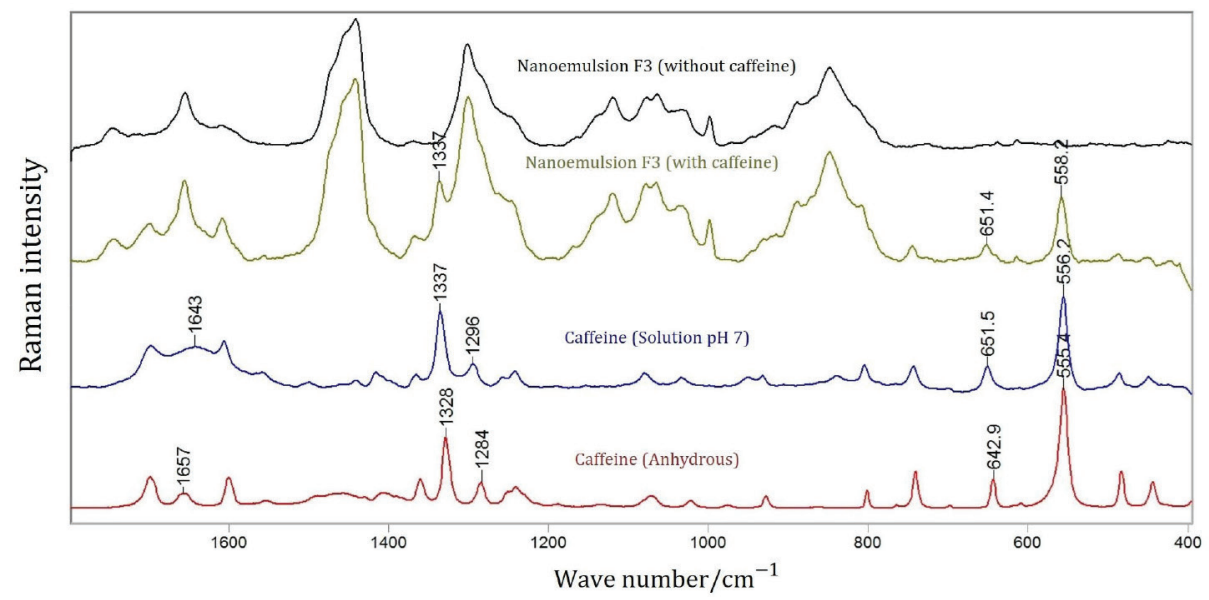

FIGURE 3 - Comparison of the Raman spectrum bands of caffeine in solution and anhydrous with the nanoemulsion $\mathbf{F 3}$ in the presence or absence of the same. 


\section{F3 (1)}

F3 (2)

F3 (3)

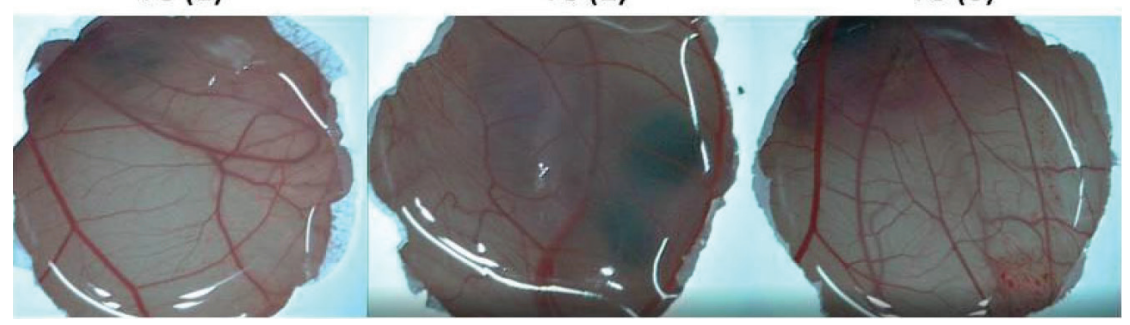

FIGURE 4 - Image of chorioallantoic membranes (CAM) after $300 \mathrm{~s}$ contact with nanoemulsion F3 (in triplicate).

\section{Skin permeation assay}

Challenging the hypothesis that the nanoemulsion may improve the cutaneous permeation, diffusion cells also called Franz cells (Smith, Haigh, 1989) were used.

The solubility of caffeine in PBS was evaluated preliminary with a value that is lower $(0.02 \mathrm{mg} / \mathrm{mL})$, relative to water solubility, than Budavari et al. (1996) $(21.74 \mathrm{mg} / \mathrm{mL})$. The soluble caffeine value in the saturated PBS buffer was $0.09 \%$, considering 21.74 $\mathrm{mg} / \mathrm{mL}$ as $100 \%$ solubility for caffeine in aqueous unsaturated solution.

Before the test, the Transepidermal Water Loss (TEWL) of skin was evaluated in order to determine its integrity and was $12.63 \mathrm{~g} / \mathrm{m}^{2} / \mathrm{h}(\mathrm{n}=3)$, which is within the range of acceptable TEWL of skin (between: $\left.6.11-47.67 \mathrm{~g} / \mathrm{m}^{2} / \mathrm{h}\right)$ (Gardien et al., 2016). The area of diffusion was $2.26 \mathrm{~cm}^{2}$ and the mean thickness of the skin was $3.67 \mathrm{~mm}$. The volume occupied by the receiving fluid was $3.0 \mathrm{~mL}$.

In vitro permeation study indicated that caffeine incorporated in F3 and the caffeine solution permeated equally statistically, with p-Value $>0.05(\alpha=0.05)$. Caffeine solution presented higher apparent permeability coefficient than $\mathbf{F 3}, 0.0024 \mathrm{~cm} / \mathrm{h}$ and $0.00005016 \mathrm{~cm} / \mathrm{h}$, respectively. These results suggested that the saturation of caffeine in the donor compartment favored the skin's permeation, although the permeated values were statistically equal. The other compartments presented the concentrations presented in Table III.

Sintov and Greenberg (2014) mentioned the low apparent permeability coefficient for the human membrane relative to other animal models such as pig.

Swabs were used to remove the excess of formulation from the skin. Thus, higher concentrations of caffeine were expected to be quantified in this location. The condition of caffeine bound in the $\mathrm{O} / \mathrm{W}$ emulsified system did not help its cutaneous permeation, however there was the visual benefit of aspect of formulation F3 with low caffeine precipitation.

\section{CONCLUSIONS}

The sub-PIT formulation methodology was effective in obtaining a monodispersed nanoemulsion with reduced average droplet diameter $(\sim 40 \mathrm{~nm})$ with a narrow distribution (PDI $<0.3)$. The best formulation was achieved using surfactant mixture HLB equal to 11.1. Caffeine-loaded nanoemulsion (F3) was found to be very stable when stored under low $\left(5.0 \pm 2.0^{\circ} \mathrm{C}\right)$ temperature condition. Raman spectra assay corroborated the low caffeine entrapment efficiency (4.8\%) and the in vitro permeation assay results, permeation assay results, suggesting that caffeine remained in the continuous phase (aqueous) probably due to the hydrophilicity of caffeine in the $\mathrm{O} / \mathrm{W}$ nanoemulsion system. However,

TABLE III - In vitro permeation profile in human skin of nanoemulsion with caffeine $1 \% \mathrm{w} / \mathrm{v}$ and caffeine solution in water ( $1 \%$ w/v) after $24 \mathrm{~h}$ assay

\begin{tabular}{cccc}
\hline & Experimental concentration $(\boldsymbol{\mu g} / \mathbf{m L}) \pm$ SD & Student's T-Test \\
\hline Location & F3 & Sol. CAF 1\% & p-value \\
\hline Swab 1 & $55.072 \pm 41.93$ & $38.5 \pm 32.38$ & 0.626 \\
Swab 2 & $36.58 \pm 27.51$ & $22.8 \pm 5.01$ & 0.187 \\
Epidermis & $0.43 \pm 0.38$ & $1.03 \pm 1.52$ & 0.573 \\
Dermis & $5.45 \pm 1.76$ & $20.55 \pm 17.84$ & 0.277 \\
\hline
\end{tabular}

Legend: $\mathbf{F 3}$ = nanoemulsion containing caffeine (1\% w/w); SD: standard deviation; SWAB: cotton swab; Sol. CAF 1\%: caffeine solution $1 \% \mathrm{w} / \mathrm{v}$. 
despite these results, the caffeine-loaded nanoemulsion presented visually and sensorially better than the solution, once solubility was improved by the surfactants added to the formulation. Thus, the developed nanoemulsion may not be a viable alternative to enhance skin permeation of hydrophilic active ingredients like caffeine, but may enhance its solubility and stability in cosmetic formulation.

\section{ACKNOWLEDGMENTS}

This work was supported by the National Council for Scientific and Technological Development (CNPq) (Project 830634/1999-1).

\section{REFERENCES}

Abd E, Namjoshi S, Mohammed YH, Roberts MS, Grice JE. Synergistic skin penetration enhancer and nanoemulsion formulations promote the human epidermal permeation of caffeine and naproxen. J Pharm Sci. 2016;105(1):212-20.

Andreev GN, Schrader B, Schulz H, Fuchs R, Popov S, Handjieva N. Non-destructive NIRFT-Raman analyses in practice. Part 1. Analyses of plants and historic textiles. Anal Bioanal Chem. 2001;371(7):1009-1017.

Anton N, Vandamme TF. The universality of low-energy nanoemulsification. Int J Pharm. 2009;377(1-2):142-147.

Baby AR, Migliato KF, Maciel CPM, Zague V, Pinto CASO, Salgado HRN, Kaneko T M, Velasco MVR. Accelerated chemical stability data of $\mathrm{O} / \mathrm{W}$ fluid emulsions containing the extract of Trichilia catigua Adr. Juss (and) Ptychopetalum olacoides Bentham. Rev Bras Cien Farm. 2007;43(3):405-412.

Bertin C, Zunino H, Pittet JC, Beau P, Pineau P, Massoneau M, Robert C, Hopkins J. A Double-blind evaluation of the activity of anti-cellulite product containing retinal, caffeine, and ruscogenine by a combination of non-invasive methods. J Cosmet Sci. 2001;52(4):199-211.

Brazil. Ministry of Health. National Sanitary Surveillance Agency. Guide to the stability of cosmetic products. Brasília: ANVISA Press; 2004. 45p.

Brazil. Câmara Técnica de Cosméticos (CATEC). Technical advice $\mathrm{n}^{\circ} 1$ [Internet]. Brasília (DF): ANVISA, 2002. [citad 2015 apr. 14]. Available from: http://portal.anvisa.gov.br/ documents/106351/107901/Parecer+T\%C3\%A9cnico+n $\% \mathrm{C} 2$ $\% \mathrm{BA}+1+\mathrm{de}+2002 /$ faald486-5bc5-44de-b1b1-2eadd540fda4 .
Budavari S, O’Neil MJ, Smith A, Heckelman PE, Kinneary JF. The Merck Index: an encyclopedia of chemicals, drugs and biological. 20th ed. New Jersey: Merck; 1996.

Dario MF, Santos MSCS, Viana AS, Arêas E.PG, Bou-chacra NA, Oliveira MC, Piedade ME M, Baby AR, Velasco MVR. A high loaded cationic nanoemulsion for quercetin delivery obtained by the sub-PIT method. Colloids Surf A Physicochem Eng Asp. 2016;489:256-264.

Edwards HGM, Munshi T, Anstis M. Raman spectroscopic characterizations and analytical discrimination between caffeine and demethylated analogs of pharmaceutical relevance. Spectrochim Acta A Biomol Spectrosc. 2005;61(7):1453-9.

Farmacopéia Brasileira 5th ed. Preparation of PBS buffer. Brasília: ANVISA, 2010. [cited 2005]. Available from: http:// www.anvisa.gov.br/hotsite/cd_farmacopeia/pdf/volume $\% 201$. pdf.

Fernandes EM, Damasceno GAB, Ferrari M, Azevedo EP. Dissolution enhancement of caffeine in the ammonium acryloyldimethyltaurate/vp copolymer base: pharmaceutical development of anti-cellulite gels Gynoid. Rev Cien Farm Bas Aplic. 2015;36(1):69-75.

Fotticchia I, Fotticchia T, Mattia CA, Netti PA, Vecchione $\mathrm{R}$, Giancola C. Thermodynamic signature of secondary nano-emulsion formation by isothermal titration calorimetry. Langmuir. 2014:30(48):14427-14433.

Gardien KLM, Baas DC, Vet HCW, Middelkoop E. Transepidermal water loss measured with the Tewameter TM300 in burn scars. Burns. 2016;42(7):1455-1462.

Gil OM. Espectroscopia Raman aplicada ao estudo da resposta bioquímica de tecidos a compostos lamelares [Master's dissertation]. São Paulo (SP): Universidade de São Paulo; 2015.

Gioia F, Celleno L. The dynamics of transepidermal water loss (TEWL) from hydrated skin. Skin Res Technol. 2002;8(3):178186.

Guirro E, Guirro R. Fisioterapia dermato Funcional: fundamentos, recursos, patologias. $3^{\mathrm{a}}$ ed. São Paulo: Manole; 2007.

Herman A, Herman AP. Caffeine's mechanisms of action and its cosmetic use. Skin Pharmacol Physiol. 2013;26(1):8-14. 
Hernández-marín NY, Lobato-Calleros C, Román-Guerrero A, Alvarez-Ramirez J, Vernon-Carter EJ. Physical properties and release behaviour of caffeine multiple emulsions stabilised by binary or ternary biopolymer soluble complexes under acid, bile and yogurt storage conditions. Food Hydrocoll. 2016;58:42-8.

ICCVAM. ICCVAM Recommended Test Method Protocol : Hen's Egg Test - Chorioallantoic Membrane ( HET-CAM ) Test Method. International Journal of Molecular Sciences [Internet] 2010. 9959-70 p. [citad 2016 Mar 16]. Available from: http:// iccvam.niehs.nih.gov/methods/ocutox/ MildMod-TMER.htm.

ICH. International Conference on Harmonization of Technical Requirements for Registration of Pharmaceuticals for Human Use. Quality Guidelines. View All Quality Guidelines. Analytical Validation Q2. Validation Of Analytical Procedures: Text And Methodology Q2 (R1) 2016 [cited 2005]. Available from: http://www.ich.org/fileadmin/Public_Web_Site/ICH_ Products/Guidelines/Quality/Q2_R1/Step4/Q2_R1_Guideline. pdf.

Izquierdo P, Esquena J, Tadros TF, Dederen C, Garcia MJ, Azemar N, Solans C. Formation and stability of nano-emulsions prepared using the phase inversion temperature method. Langmuir. 2002;18(1):26-30.

Izquierdo P, Esquena J, Tadros TF, Dederen JC, Feng J, GarciaCelma MJ. Phase behavior and nano-emulsion. Langmuir. 2004;20(16):6594-6598.

Junyaprasert VB, Teeranachaideekul V, Soutoc EB, Boonme P, Müller RH. Q10-loaded NLC versus nanoemulsions: Stability, rheology and in vitro skin permeation. Int J Pharm. 2009;377(12):207-214.

Kalweit S, Besoke R, Gerner I, Spielmann H. A national validation project of alternative methods to the Draize rabbit eye test. Toxicol in Vitro. 1990;4(4-5):702-706.

Kaszuba M. Dynamic Light Scattering. Malvern Guides. 2015, $1-26$.

Kourniatis LR, Spinelli LS, Mansur CRE, Gonz LG.Nanoemulsões/óleo de laranja/água preparadas em homogeneizador de alta pressão. Quim. Nova. 2010;33(2):295300 .

Krupek T, Costa CEM. Mecanismo de Ação de Compostos Utilizados na Cosmética para o Tratamento da Gordura Localizada e da Celulite. Saúde Pesq. 2013;5(3):555-566.
Martini E. Cationic nanoemulsions as oligonucleotide release systems: Formulation and physicochemical characterization. [Master's dissertation]. Porto Alegre: Faculty of Pharmaceutical Sciences, Federal University of Rio Grande do Sul; 2005.

Matas M, Edwards HGM, Lawson EE, Shields L, York P, Edwards HGM, Lawson EE, Shields L, York P. Ft-Raman spectroscopic investigation of a pseudopolymorphic transition in caffeine hydrate. J Mol Struct. 1998;440(1-3):97-104.

Mei Z, Liu S, Wang L, Jiang JXJ, Sun D. Preparation of positively charged oil/water nano-emulsions with a sub-PIT method. J Colloid Interface Sci. 2011;361(2):565-572.

National Institute of Environmental Health Sciences [cited 2006]. Available from: http://www.nih.gov/about-nih/whatwe-do/nih-almanac/national-institute environmental-healthsciences-niehs.

Nemen D, Lemos-Senna E. Preparação e caracterização de suspensões coloidais de nanocarreadores lipídicos contendo resveratrol destinados à administração cutânea. Quím Nova. 2011;34(3):408-413.

Oliveira CAD, Peres DDA, Graziola F, Chacra NAB, Araújo GLBD, Flórido AC. Cutaneous biocompatible rutin-loaded gelatin-based nanoparticles increase the SPF of the association of UVA and UVB filters. Eur J Pharm Sci. 2016;81:1-9.

Oliveira JMD, Mei LHI. Surfactantes reativos não-iônicos em polimerização em emulsão de látices de acetato de vinila -vinil neodecanoato: influência nas propriedades de barreira à água. Polímeros Ciência Tecnol. 2009;19(1):22-30.

Paepe KD, Roseeuw D, Rogiers V. Repair of acetone- and sodium lauryl sulphate-damaged human skin barrier function using topically applied emulsions containing barrier lipids. J Eur Acad Dermatol Venereol. 2002;16(6):587-594.

Pavel I, Szeghalmi A, Moigno D, Cîntă S, Kiefer W. Theoretical and $\mathrm{pH}$ dependent surface enhanced raman spectroscopy study on caffeine. Biopolymers. 2003;72(1):25-37.

Pianovski AR, Vilela AFG, Silva AASD, Lima CG, Silva KKD, Carvalho VFMl. Uso do óleo de pequi (Caryocar brasiliense) em emulsões cosméticas: desenvolvimento e avaliação da estabilidade física. Rev Bras Ciên Farm. 2008;44(2):249-259.

Piorkowski DT, Mcclements DJ. Beverage emulsions: Recent developments in formulation, production, and applications. Food Hydrocoll. 2014;42(pt 1):5-41. 
Pires MC, Pscheidt M. Vulvovaginites na infância: visão do dermatologista Vulvovaginites in children: a dermatologic approach. Pediatr Mod. 2017;50(5):229-32.

Ramalho A, Curvelo S. Substâncias Cosmetologicamente Activas Caracterização, indicação, eficácia e segurança: cafeína. Rev Lusófona Ciên Tec Saúde. 2006;2(3):183-90.

Rawlings AV. Cellulite and its treatment. Int J Cosmet Sci. 2006;28(3):175-90.

Ribani M, Grespan BCB, Collins CH, Fontes ICSJ, Costa LFM. Validação em métodos cromatográficos e eletroforéticos. Quim Nova. 2004;27(5):771-80.

Ribeiro C. Cosmetologia Aplicada à Dermoestética. 2nd ed. São Paulo: Pharmabooks; 2010. p. 291-296.

Rinaldo SG, Lee W, Stumper J, Eikerling M. Nonmonotonic dynamics in Lifshitz-Slyozov-Santos IMNSR, Daud FS, Santana TB, ASOP C, Mary KT, Baby AR. Gynoid lipodystrophy: general aspects and methodologies for efficacy evaluation. Arquiv Bras Cienc Saude. 2011;36(2):85-94.

Roger K, Cabane B, Olsson U. Formation of 10-100 nm sizecontrolled emulsions through a sub-PIT cycle. Langmuir. 2010; 26(6):3860-3867.

Santos IMNSR, Daud FS, Santana TB, ASOP C, Mary KT, Baby AR. Gynoid lipodystrophy: general aspects and methodologies for efficacy evaluation. Arquiv Bras Ciênc Saúde. 2011;36(2):85-94.

Sarker DK. Engineering of nanoemulsions for drug delivery. Curr Drug Deliv. 2005;2(4):297-310.

Schaffazick SR, Guterres SS, Lucca Freitas LD, Pohlmann AR. Caracterização e estabilidade físico-química de sistemas poliméricos nanoparticulados para administração de fármacos. Quim Nova. 2003;26(5):726-737.

Shakeel F, Ramadan W. Transdermal delivery of anticancer drug caffeine from water-in-oil nanoemulsions. Colloids Surf B: Biointerfaces. 2010;75(1):356-362.

Shinoda I, Saito AH. The effect of temperature on the phase equilibria and the types of dispersions of the ternary system composed of water, cyclohexane, and nonionic surfactant. [J Colloid Interface Sci. 1968;26(1):70-74.
Sintov AC, Greenberg I. Comparative percutaneous permeation study using caffeine-loaded microemulsion showing low reliability of the frozen/thawed skin models. Int J Pharm. 2014;47(1-2):516-524.

Smith W, Haigh JM. In vitro systems for assessment of drug release from topical formulations and transmembrane permeation. Percutaneous Absorption, 2nd ed. New York: Dekker; 1989. 465 p.

Tadros T, Izquierdo P, Esquena J, Solans C. Formation and stability of nano-emulsions. Adv Colloid Interface Sci. 2004;108-109:303-18.

Tagliari MP, Granada A, Kuminek G, Stulzer HK, Silva MAS. Desenvolvimento e validação de métodos analíticos para determinação de ácido glicirrízico, ácido salicílico e cafeína em nanopartículas de quitosana e alginato. Quim Nova. 2012;35(6):1228-32.

The United States Pharmacopeia Convention. The United States Pharmacopeia: the official compendia of Standards. Rockville: Asian edition; 2008, 1590 p.

United States Pharmacopeia, USP 36. The National Formulary, NF31. Rockville: United States Pharmacopeial Convention; 2013. 983-988 p.

Velasco MVR, Tano CTN, Machado-Santelli GM, Consiglieri VO, Kaneko TM, Baby AR. Effects of caffeine and siloxanetriol alginate caffeine, as anticellulite agents, on fatty tissue: Histological evaluation. J Cosmet Dermatol. 2008;7(1):23-29.

Wooster TJ, Golding M, Sanduansri P. Impact of oil type on nanoemulsion and Ostwald ripening stability. Langmuir. 2008;24(22):12758-12765.

Yukuyama MN, Ghislene DDM, Pinto TJA, Bou-Chacra NA. Nanoemulsion: process selection and application in cosmetics-a review. Int J Cosm Sci. 2016;38(1):13-24.

Zhang J, Michniak-kohn B. Investigation of microemulsion microstructures and their relationship to transdermal permeation of model drugs: Ketoprofen, lidocaine, and caffeine. Int J Pharm. 2011;421(1):34-44.

Received for publication on $25^{\text {th }}$ March 2018 Accepted for publication on $10^{\text {th }}$ July 2018 